\title{
Rumen protozoa in South African sheep with a summary of the worldwide distribution of sheep protozoa
}

\author{
Authors: \\ Dirk Booyse ${ }^{1}$ \\ Burk A. Dehority ${ }^{2}$ \\ Affiliations: \\ ${ }^{1}$ Department of Anatomy \\ and Physiology, University of \\ Pretoria, South Africa \\ ${ }^{2}$ Department of Animal \\ Sciences, Ohio State \\ University, USA \\ Correspondence to: \\ Dirk Booyse \\ Email: \\ dbooyse@op.up.ac.za \\ Postal address: \\ Private Bag X04 \\ Onderstepoort 0110, \\ South Africa \\ Dates: \\ Received: 16 Nov. 2010 \\ Accepted: 16 Feb. 2011 \\ Published: 21 July 2011 \\ How to cite this article: \\ Booyse, D. \& Dehority, B.A., \\ 2011, 'Rumen protozoa in \\ South African sheep with a \\ summary of the worldwide \\ distribution of sheep \\ protozoa', Onderstepoort \\ Journal of Veterinary \\ Research 78(1), Art. \#307, \\ 7 pages. doi:10.4102/ojvr. \\ v78i1.307
}

C 2011. The Authors. Licensee: OpenJournals Publishing. This work is licensed under the Creative Commons Attribution License.
Protozoa species were identified in rumen contents of four domestic sheep (Ovis aries) from South Africa. All animals were fed a forage diet which consisted of 50\% lucerne and 50\% teff hay. Ten new host records were identified, bringing the total number of species and forms observed in sheep in South Africa to 30. The occurrence and geographic distribution of ciliate protozoa in both domestic and wild sheep from around the world are summarised. It was found that 15 genera and 131 species occur in domestic sheep globally.

\section{Introduction}

Other than several early reports from South Africa on rumen ciliate protozoa in domestic sheep (Fantham 1920, 1921, 1926; Van der Wath \& Myburgh 1941), no additional research in this respect has been published. These previous studies identified a total of only 12 species and forms. Studies from other areas of Africa are also limited (see, e.g. Selim et al. [1996] for Egypt and Selim et al. [1999] for Libya). To date only 17 species have been observed in domestic sheep across Africa.

\section{Materials and methods}

During August 2009 samples of rumen contents were obtained from four fistulated male domestic sheep (Ovis aries), which were all housed together in $6 \mathrm{~m} \times 10 \mathrm{~m}$ pens at the Department of Anatomy and Physiology, University of Pretoria (Onderstepoort), South Africa. Half of each pen was covered by a concrete floor, whilst the other half was an open-air dirt floor. The animals were rotated to a clean pen every week. The sheep were fed a 50:50 mixture of lucerne (Medicago sativa) and teff hay (Eragrostis tef) each morning, after which they were allowed free access to kikuyu grass (Pennisetum clandestinum) pasture for the rest of the day. Rumen samples of $200 \mathrm{~mL}$ each were collected through rumen fistulas and $200 \mathrm{~mL}$ warm saline was added immediately to each sample. This helped to extend the cilia of the protozoa for easier identification. The sample was then preserved by adding $70 \%$ alcohol $(100 \mathrm{~mL})$.

Each sample was washed in a Pitchford-Visser filter, similar to the one used for trematode egg counts. The outer sieve had an aperture of $37 \mu \mathrm{m}$, whilst apertures in the inner sieve were $110 \mu \mathrm{m}$. This procedure retained all the coarse material in the inner sieve and the protozoa were captured in the outer sieve. The sample was recovered from the outer sieve by means of a drain tap. The washed sample was drained into a container, allowed to stand and settle for $15 \mathrm{~min}$ and then most of the supernatant was decanted. This allowed concentration of the sample to a final volume of $40 \mathrm{~mL}$. A measured volume of alcohol was added to preserve the sample. A few drops of methyl blue stain were added to stain the protozoa and nucleus (Booyse, Boomker \& Dehority 2010).

A 0.1-mL aliquot of stained sample was transferred onto a glass microscope slide using a 'Finnpipette', commonly used in chemistry laboratories. The sample was covered with a glass cover slip and examined with a standard Nikon microscope fitted with a Panasonic digital camera. Photographs were taken to aid identification. Each sample was examined in triplicate.

Owing to the observed lack of Entodinium spp. in the washed samples, additional samples of rumen contents from the four sheep were obtained. Sub-samples $(0.1 \mathrm{~mL})$ of these samples were stained and examined under the microscope to verify the presence of Entodinium spp., which had been lost through the $37-\mu \mathrm{m}$ filter.

\section{Ethical considerations}

Housing and care of fistulated animals in the Department of Anatomy and Physiology were approved on an ongoing basis by the University of Pretoria Animal Care and Use Committee, as sheep are routinely used as rumen fluid donors, both for experimental and for teaching purposes. 


\section{Results and discussion}

A total of 20 species and forms of protozoa were observed in the four sheep used in the present study. Of these species, 10 were identified in South Africa for the first time (Table 1). This brings the total number of species and forms reported from sheep in South Africa to 30. All Entodinium species listed in Table 1 were identified in whole rumen content (i.e. unfiltered samples). It is noteworthy that for these new host records in South Africa at least three of the Entodinium species are closely related or possibly similar to Entodinium dubardi (Dehority 1994). These are Entodinium caudatum f. dubardi, Entodinium parvum and Entodinium simplex. Entodinium nanellum would have been included in this group, but had been observed previously. Two of the other Entodinium species reported as a new host record, namely Entodinium exiguum and Entodinium longinucleatum, can occur on a variation line with E. dubardi. However, two rather distinctive features allow identification as a separate species: for E. exiguum, a straight oesophagus that does not curve towards the macronucleus, and for $E$. longinucleatum, a macronucleus extending the entire length of the cell.
The number of species and forms observed for other geographical locations range from fewer than 10 to 49 , as shown in Table 2. The number found in the present study is about halfway between these extremes. In general, several reports where only a limited number of species were observed, appear not to be comprehensive studies; that is, only a few species were identified rather than a complete listing of all species present. Göçmen et al. (1999) observed that the protozoan fauna of sheep in Turkey and Far Eastern areas (e.g. China and Japan) appeared to be more diverse than in European and American sheep.

A number of the studies listed in Table 2 were reported between 1920 and 1985, before the most widely used classification scheme of Lee, Hutner and Bovee (1985) was published. Therefore, the older species names in the subfamily Diplodiniinae listed in the original reports have been corrected according to the more recent classification scheme. For example, Eodinium spp. are now classified under Diplodinium and Eremoplastron spp. under Eudiplodinium. Diploplastron affine is now classified as Metadinium affine. In more recent studies by Göçmen (1999a, 1999b), classification

TABLE 1: Rumen ciliate protozoa observed in domestic sheep (Ovis aries) in South Africa.

\begin{tabular}{|c|c|c|c|c|c|}
\hline Species and forms & Present study & Fantham (1920) & Fantham (1921) & Fantham (1926) & Van der Wath and Myburgh (1941) \\
\hline Isotricha intestinalis & + & + & - & - & - \\
\hline Isotricha prostoma & + & + & - & - & - \\
\hline Dasytricha ruminantium & + & + & - & - & - \\
\hline Entodinium bursa & - & + & - & - & - \\
\hline Entodinium caudatum & - & - & - & - & - \\
\hline f. caudatum & + & - & + & - & - \\
\hline f. dubardi & ++ & - & - & - & - \\
\hline Entodinium dubardi & + & - & - & + & + \\
\hline Entodinium elongatum & - & - & - & - & + \\
\hline Entodinium exiguum & ++ & - & - & - & - \\
\hline Entodinium furca & - & - & - & - & + \\
\hline Entodinium longinucleatum & ++ & - & - & - & - \\
\hline Entodinium minimum & - & - & - & + & - \\
\hline Entodinium nanellum & + & - & - & + & + \\
\hline Entodinium simplex & ++ & - & - & - & - \\
\hline Diplodinium dentatum & + & - & - & + & - \\
\hline Diplodinium polygonale & - & - & - & + & - \\
\hline Ostracodinium crassum & - & - & - & + & - \\
\hline Ostracodinium gracile & ++ & - & - & - & - \\
\hline Ostracodinium trivesiculatum & ++ & - & - & - & - \\
\hline Eudiplodinium neglectum & - & - & - & + & - \\
\hline Enoploplastron triloricatum & ++ & - & - & - & - \\
\hline Polyplastron multivesiculatum & ++ & - & - & - & - \\
\hline Epidinium ecaudatum & - & - & - & - & - \\
\hline f. ecaudatum & - & + & - & - & - \\
\hline f. caudatum & + & + & - & - & - \\
\hline f. bicaudatum & - & + & - & - & - \\
\hline f. tricaudatum & - & + & - & - & - \\
\hline Ophryoscolex caudatus & + & - & - & + & - \\
\hline f. bicoronatus & + & - & - & + & - \\
\hline f. purkynjei & ++ & - & - & - & - \\
\hline Total species and forms & 20 & 8 & 1 & 9 & 4 \\
\hline
\end{tabular}

Note: Please see the full reference list of the article, Booyse, D. \& Dehority, B.A., 2011, 'Rumen protozoa in South African sheep with a summary of the worldwide distribution of sheep protozoa', Note: Please see the full reference list of the article, Booyse, D. \& Dehority, B.A., 2011, 'Rumen protozoa in South African she
Onderstepoort Journal of Veterinary Research 78(1), Art. \#307, 7 pages. doi:10.4102/ojvr.v78i1.307, for more information. 


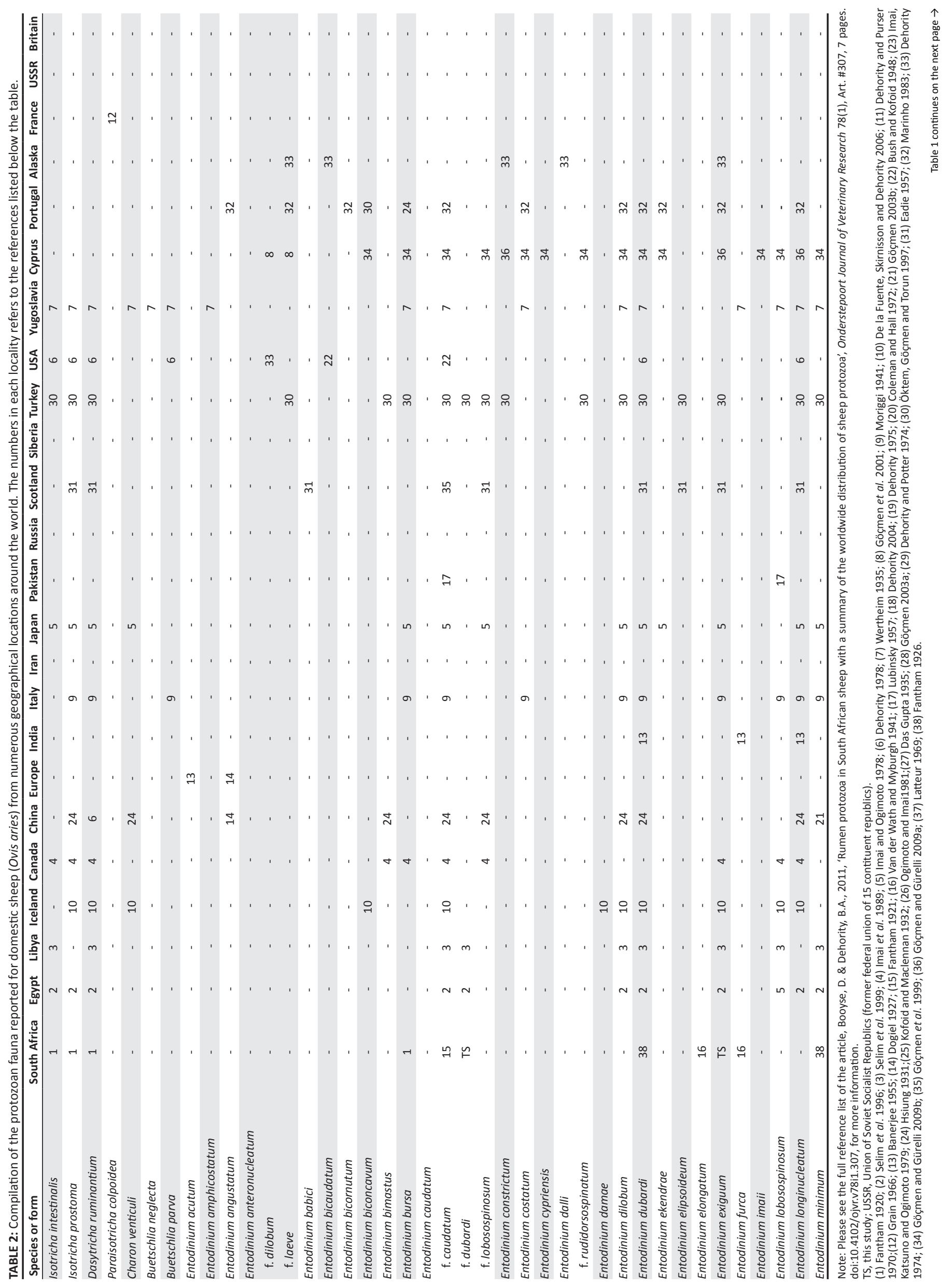




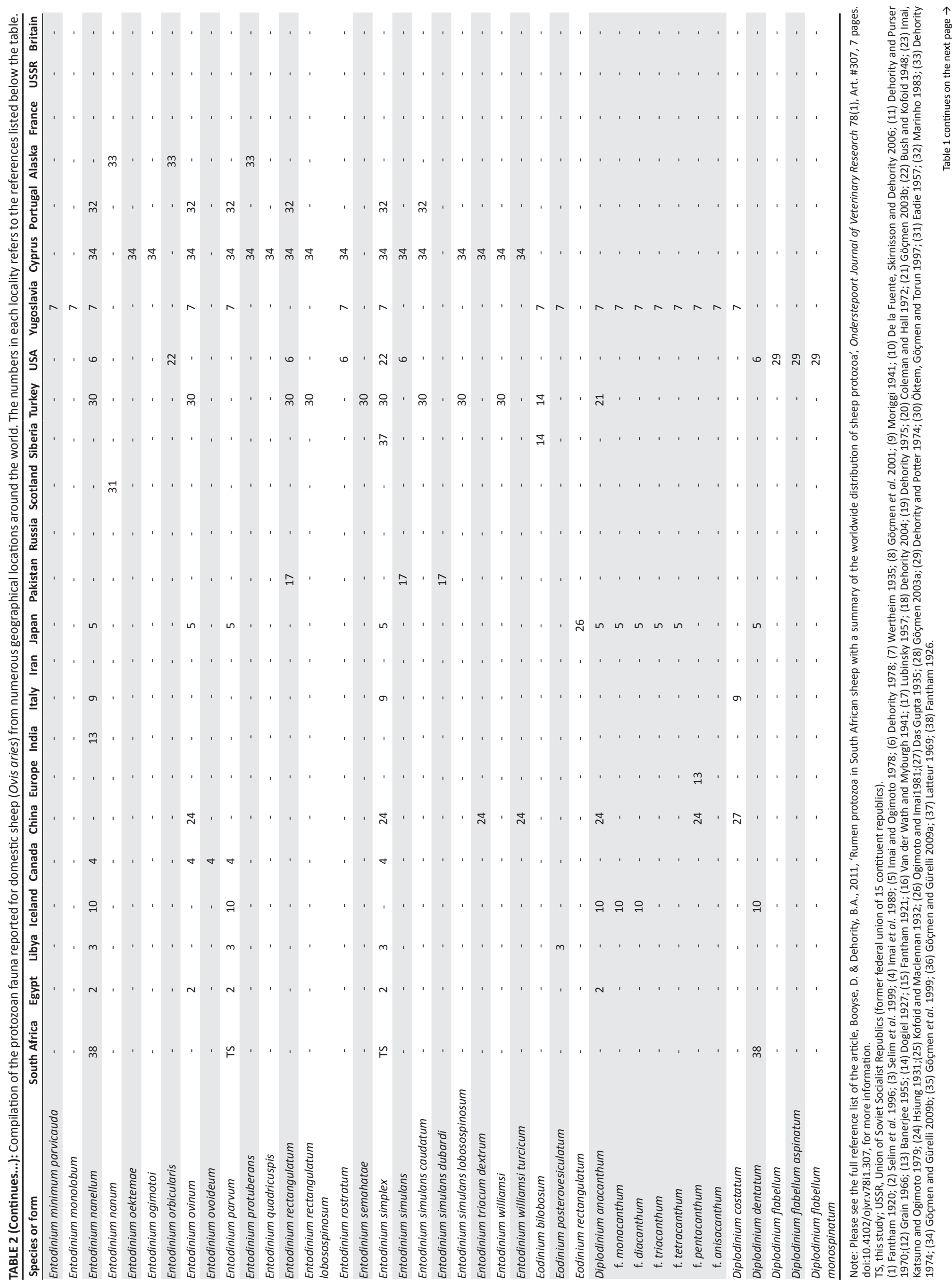




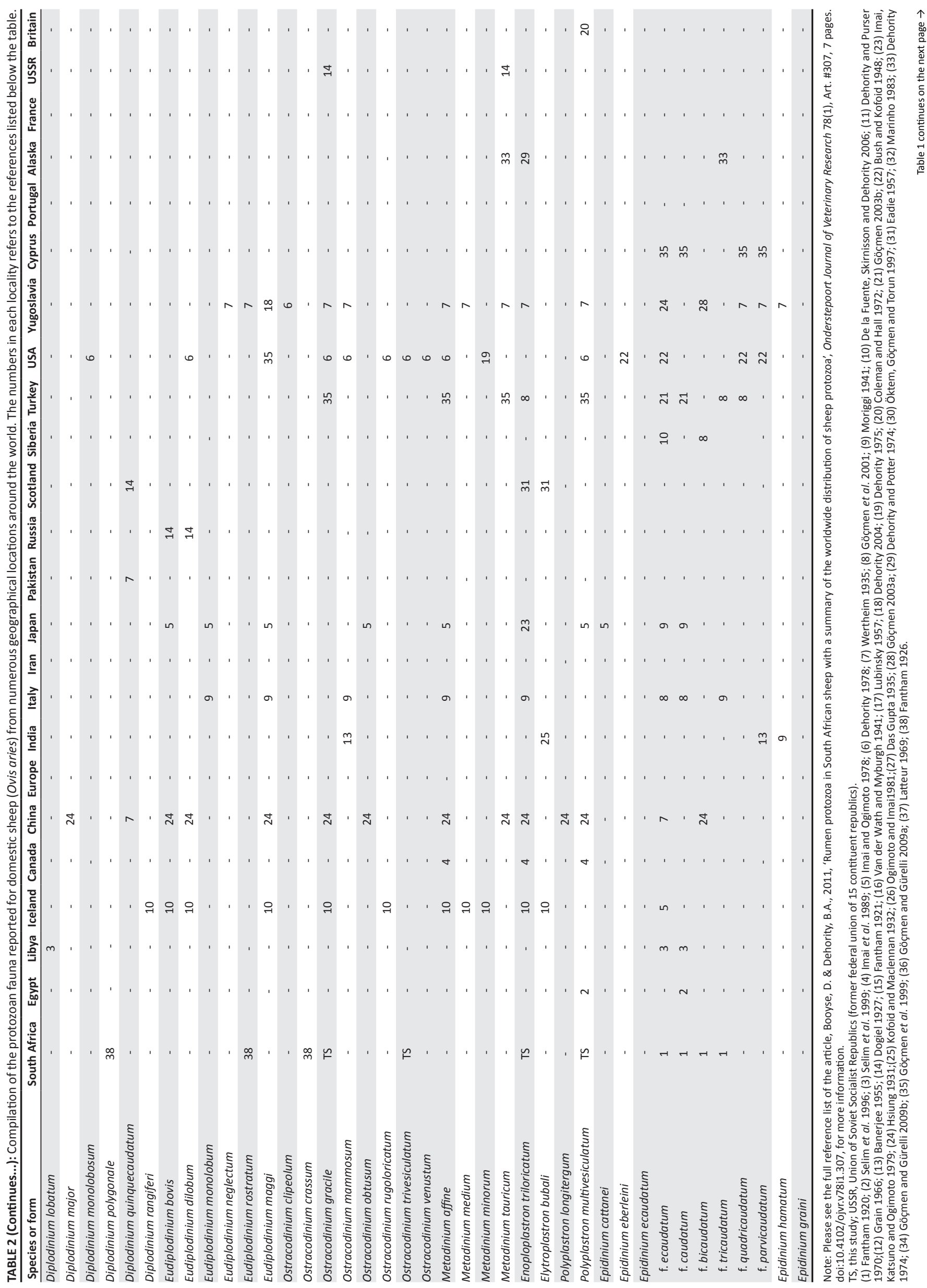




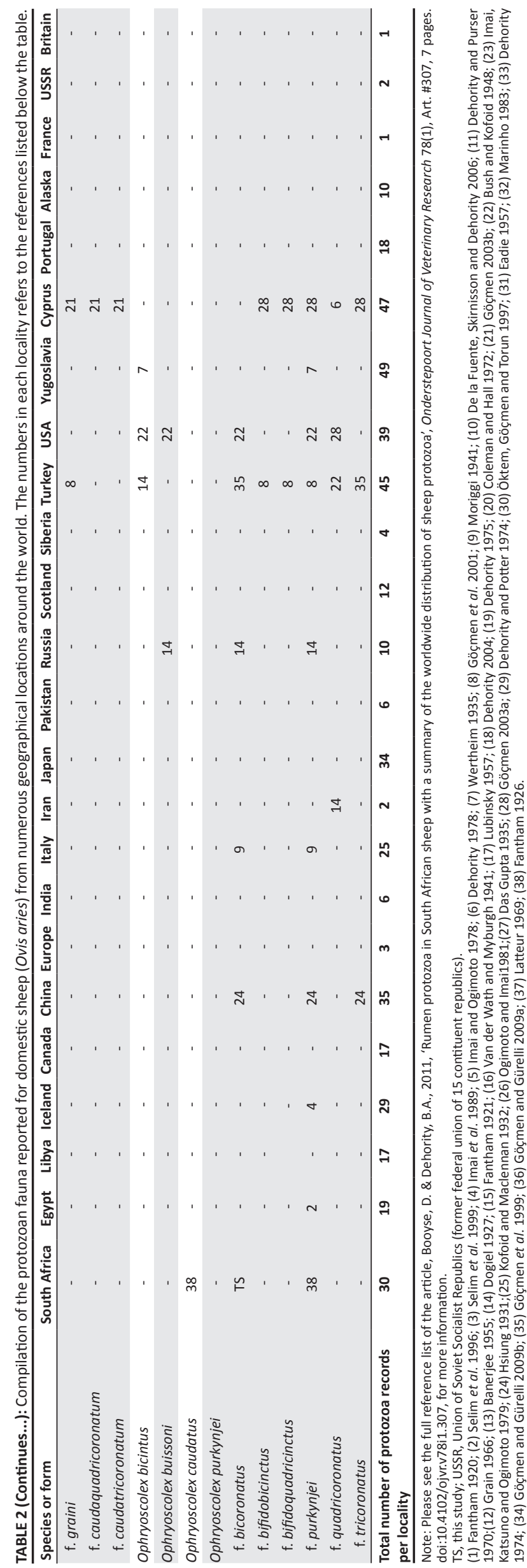

TABLE 3: Protozoa recorded in Bighorn (Ovis canadensis) and Dall (Ovis dalli) sheep. The numbers in each locality refers to the references listed below the table.

\begin{tabular}{|c|c|c|c|c|}
\hline Protozoa listed per host & California & Scotland & Siberia & Alaska \\
\hline Bighorn sheep & - & - & - & - \\
\hline Entodinium bicarinatum & - & - & 3 & - \\
\hline Entodinium bicaudatum $\dagger$ & 1 & - & - & - \\
\hline Entodinium chatterjee & 1 & - & - & - \\
\hline Entodinium exiguum† & 1 & - & - & - \\
\hline Entodinium nanum $\dagger$ & 1 & 3 & - & - \\
\hline Entodinium orbicularis† & 1 & - & - & - \\
\hline Entodinium truncatum & 1 & - & - & - \\
\hline Enoploplastron triloricatum $\dagger$ & 1 & - & - & - \\
\hline Metadinium tauricum $\dagger$ & 1 & - & - & - \\
\hline Polyplastron californiense & 1 & - & - & - \\
\hline Dall sheep & - & - & - & - \\
\hline Entodinium anteronucleatum $\dagger$ & - & - & - & 2 \\
\hline Entodinium bicaudatum $\dagger$ & - & - & - & 2 \\
\hline Entodinium constrictum $\dagger$ & - & - & - & 2 \\
\hline Entodinium dalli & - & - & - & 2 \\
\hline Entodinium nanum $\dagger$ & - & - & - & 2 \\
\hline Metadinium tauricum $\dagger$ & - & - & - & 2 \\
\hline Polyplastron alaskum & - & - & - & 2 \\
\hline Ophryoscolex bicinctus & - & - & - & 2 \\
\hline Ophryoscolex buissoni† & - & - & - & 2 \\
\hline Ophryoscolex purkynjei† & - & - & - & \\
\hline f. bicoronatus $\dagger$ & - & - & - & 2 \\
\hline f. caudatus $\dagger^{* *}$ & - & - & - & 2 \\
\hline Total number of species and forms & 9 & 1 & 1 & 11 \\
\hline
\end{tabular}

$\uparrow$ Protozoa recorded in domestic sheep.

(1) Bush, M. \& Kofoid, C.A., 1948, 'Ciliates from the Sierra Nevada bighorn (Ovis canadensis sierrae Grinnell)', University of California Publications in Zoology 53, 287-261; (2) Dehority, B.A., 1974, 'Rumen ciliate fauna of Alaskan Moose (Alces Americana), Musk-Ox (Ovisbos moschantus) and Dall Mountain sheep (Ovis dalli)', Journal of Protozoology 21, 26-32; (3) Latteur, B., 1969, 'Rivision systématique de la Famille des Ophryoscolecidae Stein, 1858: Latteur, B., 1969, 'Rivision systématique de la Famille des Ophryoscolecidae Stein, 1858:
sous-Famille des Entodiniinae Lubinsky, 1957, Genre Entodinium Stein, 1958', Annales de la sous-Famille des Entodiniinae Lubinsky, 1957, Ge
Scociete Royal Zoologique de Belgique 99, 3-25.

of both Epidinium spp. and Ophryoscolex spp. have been redefined and are used in Table 2. The total number of protozoa found in each of the localities indicated in Table 2 is summarised and listed at the end of the table.

Table 3 lists species and forms of protozoa observed in wild Bighorn and Dall sheep in the USA. Bighorn sheep are found in the Rocky Mountains from Colorado to Canada, whilst the Dall sheep live further north, reaching into Alaska. Many of the protozoa found in these two species (10 in Bighorn and 11 in Dall sheep) are also present in domestic sheep. Although not reported from domestic sheep, at least two species have been observed in Turkish cattle, namely Entodinium dalli, and a second form, Entodinium dalli rudidorosospinatum (Göçmen \& Öktem 1996). Of particular interest is the presence of two new species of Polyplastron, neither of which has been observed elsewhere.

It is possible that as further in-depth studies are conducted, we will find a somewhat uniform distribution of protozoal species around the world.

\section{Conclusion}

We identified 10 species of rumen ciliate protozoa that had not been previously observed in rumen contents of South 
African sheep. This brings the total of species observed in this country to 30. The collection of protozoal fauna in South African sheep was compared to previous data reported for sheep worldwide and appeared to be somewhat less diverse.

\section{References}

Banerjee, K., 1955, 'Studies on parasitic ciliates from Indian ruminants', Proceedings of the Zoological Society 8, 87-101.

Booyse, D.G., Boomker, E.A. \& Dehority, B.A., 2010, 'Protozoa in the digestive tract of wild herbivores in South Africa, I: Warthogs (Phacochoerus aethiopicus)', Zootaxa 2492, 63-68.

Bush, M. \& Kofoid, C.A., 1948, 'Ciliates from the Sierra Nevada bighorn (Ovis canadensis sierrae Grinnell)', University of California Publications in Zoology 53, 287-261.

Coleman, G.S. \& Hall, F.J., 1972, 'Fine structural studies on the digestion of bacteria species in the rumen ciliate Entodinium caudatum', Tissue and Cell 4, 37-38. doi:10.1016/S0040-8166(72)80004-1

Das Gupta, M., 1935, 'Preliminary observations on the protozoan fauna of the rumen of the Indian goat, Capra hircus Linn.', Archiv für Protistenkunde 85, 153-172.

De la Fuente, G., Skirnisson, K. \& Dehority, B.A., 2006, 'Rumen ciliate fauna of Icelandic cattle, sheep, goat and reindeer', Zootaxa 1337, 47-60.

Dehority, B.A., 1974, 'Rumen ciliate fauna of Alaskan moose (Alces Americana), musk-ox (Ovisbos moschantus) and Dall Mountain sheep (Ovis dalli)', Journal of Protozoology 21, 26-32.

Dehority, B.A., 1975, 'Diplodinium (Ostracodinium) minorum sp.n., ciliate from the rumen of domestic sheep', Journal of Protozoology 22, 328-330.

Dehority, B.A., 1978, 'Specificity of rumen ciliate protozoa in cattle and sheep', Journal of Protozoology 25, 509-513.

Dehority, B.A., 1994, 'Rumen ciliate protozoa of the blue duiker (Cephalophus monticola), with observations on morphological variation lines within the
species Entodinium dubardi', Journal of Eukaryotic Microbiology 41, 103-111. species Entodinium dubardi', Journal of Eukaryotic Microbi
doi:10.1111/j.1550-7408.1994.tb01481.x, PMid:8167616.

Dehority, B.A., 2004, 'In vitro determination of generation times for Entodinium exiguum, Ophryoscolex purkynjei and Eudiplodinium maggii', Journal of Eukaryotic Microbiology 5, 333-338. doi:10.1111/j.1550-7408.2004.tb00575.x, PMid:15218703.

Dehority, B.A. \& Potter, E.L., 1974, 'Diplodinium flabellum: Occurrence and numbers in rumen of sheep with a description of two new subspecies', Journal of Protozoology 21, 686-693.

Dehority, B.A. \& Purser, D.B., 1970, 'Factors effecting the establishment and numbers of holotrich protozoa in the ovine rumen', Journal of Animal Science 30, 445-449. PMid:5436455

Dogiel, V.A., 1927, 'Monographie der Familie Ophryoscolecidae', Archiv für Protisenkunde 59, 1-288.

Eadie, J.M., 1957, 'The mid-winter rumen microfauna of the seaweed-eating sheep of North Ronaldshay', Proceedings of the Royal Society of Edinburgh Series B 66, 276-287.

Fantham, H.B., 1920, 'Some parasitic protozoa found in South Africa III', South Africa Journal of Science 17, 131-135.

Fantham, H.B., 1921, 'Some parasitic protozoa found in South Africa IV', South African Journal of Science 18, 164-170.

Fantham, H.B., 1926, 'Some parasitic protozoa found in South Africa. IX', South African Journal of Science 23, 560-570.

Göçmen, B., 1999a, 'Morphological and taxonomical investigations on the genus of Ophryoscolex Stein, 1858 (Protozoa: Ciliophora: Entodiniomorphida)', Turkish Journal of Zoology 23, 397-427.

Göçmen, B., 1999b, 'Morphological and taxonomical investigations on the genus Epidinium Crawley, 1923 (Protozoa: Ciliophora: Entodiniomorphida)', Turkish Journal of Zoology 23, 429-463.

Göçmen, B, 2003a, 'The Rumen ophryoscolecid (Entodiniorphida) ciliate, Ophryoscolex purkynjei Stein, 1858 (Sensu Göçmen, 1999) of domestic sheep (Ovis ammon aries) from Cyprus', Turkiye Parazitoloji Dergisi 27, 273-279.

Göçmen, B., 2003b, 'Rumen Ophryoscolecid (Entodiomorphida) ciliate genus Epidinium (Crawley, 1923) living in the domestic sheep from Cyprus', Turkiye Parazitoloji Dergisi 27, 280-286.
Göçmen, B. \& Gürelli, G., 2009a, 'The occurrence of the rumen ciliate Entodinium constrictum Dehority, 1974 (Entodiniidae, Entodiniomorphida) from sheep (Ovis ammon aries) in Northern Cyprus', North-Western Journal of Zoology 5, 301-306.

Göçmen, B. \& Gürelli, G., 2009b, 'Rumen entodiniid ciliated protozoan fauna (Entodiniomorphida: Entodiniidae) of domestic sheep (Ovis ammon aries L.) from Northern Cyprus, with a description of a new species, Entodinium cypriensis sp. nov.', Turkish Journal of Zoology 33, 169-180.

Göçmen, B. \& Öktem, N., 1996, 'New rumen ciliates from Turkish domestic cattle (Bos taurus L): The presence of Entodinium dalli Dehority, 1974 with a new forma,
Entodinium dalli rudidorsospinatum n. f. and comparisons with Entodinium Entodinium dalli rudidorsospinatum n. f. and comparisons
williamsi n. sp.', European Journal of Protistology 32, 513-522.

Göçmen, B., Torun, S. \& Öktem, N., 1999, 'A preliminary study on the rumen ciliate fauna of Turkish domestic sheep (Ovis ammon aries): Family Ophryoscolecidae (Entodiniomorphida)', Turkish Journal of Zoology 23, 473-490.

Göçmen, B., Dehority, B., Talu, D.H. \& Rastgeldy, S., 2001, 'The rumen ciliate ophryoscolecid (Entodiniomorphida) and isotrichid (Trichostomatida) fauna of domestic sheep (Ovis ammon aries) from the Turkish Republic of Northern Cyprus', Journal of Eukaryotic Microbiology 48, 455-459. doi:10.1111/j.1550-7408.2001. tb00179.x, PMid:11456322

Grain, J., 1966, 'Etude cytoloqique de quelques cillies holotriches endocommensaux des ruminants et des equides', Protistologica 2, 59-141.

Hsiung, T.-S., 1931, 'The protozoan fauna of the rumen of Chinese sheep', Bulletin of the Fan Memorial Institute of Biology 2, 29-41.

Imai, S., Han, S.S., Cheng, K.J. \& Kudo, H., 1989, 'Composition of the rumen ciliate population in experimental herds of cattle and sheep in Leithbridge, Alberta, Western Canada', Canadian Journal of Microbiology 35, 686-690. doi:10.1139/ m89-112, PMid:2504472

Imai, S., Katsuno, M. \& Ogimoto, K., 1979, 'Type of the pattern of the rumen ciliate composition of the domestic ruminants and the predator-prey interaction of ciliates', Japanese Journal of Zootechnical Science 50, 79-87.

Imai, S. \& Ogimoto, K., 1978, 'Scanning electron and fluorescent microscopic studies on attachment of spherical bacteria to ciliate protozoa in ovine rumen', Japanese Journal of Veterinary Science 40, 9-19. PMid:417206

Kofoid, C.A. \& Maclennan, R.F., 1932, 'Ciliates from Bos indicus Linn. II. A revision of Diplodinium Schuberg', University of California Publications in Zoology 37, 53-152.

Latteur, B., 1969, 'Rivision systématique de la Famille des Ophryoscolecidae Stein, 1858: sous-Famille des Entodiniinae Lubinsky, 1957, Genre Entodinium Stein, 1958', Annales de la Scociete Royal Zoologique de Belgique 99, 3-25.

Lee, J.J., Hutner, S.H. \& Bovee, E.C., 1985, An Illustrated Guide to the Protozoa, Society of Protozoologists, Lawrence.

Lubinsky, G., 1957, 'Studies on the Evolution of the Ophryoscolecidae (Ciliata: Oligotricha) A new species of Entodinium with "caudatum", "Iobosospinosum" and "dubardi" forms, and some evolutionary trends in the genus Entodinium", Canadian Journal of Zoology 35, 111-128. doi:10.1139/257-007

Marinho, A.A., 1983, 'Protozoários cilliados no rumen de ovinos em pastoreio', Revisto Portuguesa Cincias Veterinarias 78, 157-165.

Moriggi, M., 1941, 'Ricerche sugli infusori dei Ruminanti Italiani', Archivio Zoologico Itaiano Pubblicato Sotto gli Auspicii della Unione 29, 396-412.

Ogimoto, K. \& Imai, S., 1981, Atlas of Rumen Microbiology, Japan Scientific Societies Press, Tokyo.

Öktem, N., Göçmen, B. \& Torun, S., 1997, 'Turkiye evcil koyun (Ovis ammon aries)'larinin işkembe Siliyat (Protozoa: Ciliophora) Faunasi Hakkinda Bir Ön Calişma: I- Familya Isotrichidae (Trichostomatida) ve Entodiniidae (Entodiniomorphida)', Turkish Journal of Zoology 21, 475-502.

Selim, H.M., Imai, S., Yamato, O., El Kabbany, A., Kiroloss, F. \& Maede, Y., 1996, 'Comparative study of rumen ciliates in buffalo, cattle and sheep in Egypt', Journal of Veterinary and Medical Science 58, 799-801. doi:10.1292/jvms.61.303

Selim, H.M., Imai, S., Sheik, A.K., Attia, H., Okamoto, E., Miyagawa, E. et al., 1999 'Rumen ciliate protozoal fauna of native sheep, Friesian cattle and dromedary camel in Libya', Journal of Veterinary and Medical Science 61, 303-305.

Van der Wath, J.G. \& Myburgh, S.J., 1941, 'Studies on the alimentary tract of merino sheep in South Africa. VI. The role of infusoria in ruminal digestion with some remarks on ruminal bacteria', Onderstepoort Journal of Veterinary Science and Animal Industry 17, 61-85.

Wertheim, P., 1935, 'Infusorien aus dem Widerkauermagen von Gebiete Jugoslawiens nebs einer Ubersicht dieser Tierchen von Balkanhalbinsel Bereich und ein kurzer Bericht uber die Pferdedarminfusorien, zugleich Revision der Familie Ophryoscolecidae', Veterinarski Archiv 5, 386-537. 